\title{
Cost-Effectiveness Analysis of Immunotherapy in Patient with Allergic Rhinitis
}

\author{
Joon Yong Park ${ }^{1}$ (D), Yoon-Sook Kim ${ }^{2}$ (D) Jin Kook Kim ${ }^{1}$ (D), Jae Hoon Cho ${ }^{1,2}$ (D) \\ ${ }^{1}$ Department of Otorhinolaryngology-Head and Neck Surgery, School of Medicine, Konkuk University, Seoul; and \\ ${ }^{2}$ Department of Quality Improvement, Konkuk University Medical Center, Seoul, Korea
}

\section{알레르기 비염 면역치료의 비용효과 분석}

박준용 $^{1} \cdot$ 김윤숙 ${ }^{2} \cdot$ 김진국 $^{1} \cdot$ 조재훈 ${ }^{1,2}$

건국대학교 의학전문대학원 이비인후-두경부외과학교실, ${ }^{1}$ 건국대학교병원 적정진료팀 ${ }^{2}$

\author{
Received August 17, 2020 \\ Revised December 8, 2020 \\ Accepted December 16, 2020 \\ Address for correspondence \\ Jae Hoon Cho, MD, PhD, MPH \\ Department of Otorhinolaryngology- \\ Head and Neck Surgery, \\ School of Medicine, \\ Konkuk University, \\ 120-1 Neungdong-ro, Gwangjin-gu, \\ Seoul 05030, Korea \\ Tel $+82-2-2030-7667$ \\ Fax $+82-2-2030-5299$ \\ E-mail jaehoon@kuh.ac.kr
}

Background and Objectives All treatments must be effective and affordable. Although it is clear that immunotherapy is effective in patients with allergic rhinitis, no cost-effectiveness analysis has been conducted in Korea.

Subjects and Method We compared 10 years of total treatment costs (medical expense+ transportation cost+time cost) with medications and symptoms scores assuming that adult patients with allergic rhinitis are treated only with symptomatic medication (medication model) or immunotherapy (subcutaneous or sublingual) plus symptomatic medication [subcutaneous immunotherapy (SCIT) and sublingual immunotherapy (SLIT) models, respectively]. For cost-effectiveness analysis, related papers and domestic medical statistics were used.

Results The total treatment costs for the first 3 years were 3330199 , $\$ 6605557$, and \#130467 for the Medication model, SCIT model and SLIT model, respectively. The total treatment costs for the 10 -year period were $\$ 7996087$, $\$ 8588624$, and $\$ 9113534$ for the medication model, SCIT model, and SCIT model, respectively. The cumulative symptoms plus medications scores decreased 0.44 times in both immunotherapy models compared to the medication model.

Conclusion The initial cost of immunotherapy is more expensive than symptomatic medication, but the total cost for 10 years is similar. In addition, immunotherapy can reduce symptoms by more than half. Therefore, it is a cost-effective treatment for allergic rhinitis.

Korean J Otorhinolaryngol-Head Neck Surg 2021;64(8):554-62

Key Words Allergic rhinitis · Cost-effectiveness analysis · Immunotherapy.

\section{서 론}

알레르기 비염은 특정 항원에 대한 과민반응으로 반복적인 재채기, 콧물, 코막힘, 가려움증 등의 증상을 동반한다. ${ }^{1)}$ 환자 본인 삶의 질이 심각하게 저하되는 것도 문제지만, 높은 유병 률로 인해 사회 전체의 부담도 큰 질환이다. ${ }^{2)}$ 국내 알레르기

This is an Open Access article distributed under the terms of the Creative Commons Attribution Non-Commercial License (https://creativecommons.org/licenses/by-nc/4.0) which permits unrestricted non-commercial use, distribution, and reproduction in any medium, provided the original work is properly cited.
비염의 유병률은 1999 년 소아 $15.5 \%$, 성인 $19.3 \%$ 였고, ${ }^{3)}$ 국민 건강보험공단 자료에 따르면 2004 2010년 전국의 알레르기 비염 유병률은 $7.24 \%$ 에서 $10.85 \%$ 로 증가하였다. ${ }^{4)}$ 특히, 18세 미만의 경우 $10.98 \%$ 에서 $18.81 \%$ 로 급격히 증가하였다.) 또 한 2016년 발표된 보고서에 따르면 알레르기 비염으로 인해 우리나라가 한 해 지출하는 사회경제적 비용은 약 1 조 2960 억 원으로, 이는 국내 총 GDP의 $0.09 \%$ 에 이르는 막대한 금 액이다. ${ }^{2)}$ 따라서 알레르기 비염 환자에 대한 효과적이고도 경 제적인 치료가 매우 절실하다. 
알레르기 비염 치료를 위해 매우 다양한 시도가 이루어지 고 있지만, 현재 가장 보편적인 치료법은 항히스타민제, 류코 트리엔 수용체 길항제, 비점막수축제 등의 경구용 약물과, 스 테로이드나 항히스타민제 성분의 스프레이를 증상이 악화될 때 마다 반복적으로 사용하는 것이다. ${ }^{1)}$ 하지만, 이러한 약물 요법은 단지 대증적이고 효과도 일시적이다. 반면 면역치료는 알레르기 비염을 일으키는 원인 항원을 찾아 인체에 반복적 으로 투여함으로써 내성을 유도하는 치료법으로 병을 근본 적으로 호전시키며 알레르기 비염이 천식으로 진행하는 것도 막을 수 있는 방법이다. ${ }^{5)}$ 면역치료의 정확한 기전에 대해서는 이견이 있지만 IL-12와 조절 T세포를 증가시켜 궁극적으로 Th2 반응이 Th1 반응으로 전환되는 것이 주요 기전으로 알 려져 있다. ${ }^{5)}$ 면역치료는 피하면역치료와 경구면역치료의 두 종류가 있으며, 모두 알레르기 비염 치료에 효과적이라는 사 실이 여러 연구에서 증명되었다. ${ }^{6}$ 하지만 3년 이상의 치료기 간이 필요하고, 약물이 고가인데 아직 보험적용이 되지 않으 며, 치료를 중단한 후 알레르기 비염이 다시 악화될 수 있다 는 단점이 있다.

최근 의료의 전 분야에 걸쳐 비용효과분석(cost-effectiveness analysis)이 매우 중요한 문제가 되었다. 극, 기존의 치료 법에 비해 의학적 관점에서 조금 더 효과적인 새로운 치료법 개발되었다고 해도 비용이 너무 비싸면, 결과적으로 비용당 효과가 낮아 사회적으로 받아들이기 어렵다. 반대로 기존의 치료법에 비해 효과가 아주 뛰어나면서 비용이 조금만 증가 한 경우나 효과가 비슷하다 해도 비용이 저렴해진 경우 비용 당 효과가 높아져 사회 전체적으로 새로운 치료법을 받아들 이는 것이 이익이 된다. ${ }^{7)}$ 알레르기 비염 환자에서 면역치료를 시행한 경우 고가의 시약으로 인해 일반적인 약물요법에 비해 초기 치료비용이 더 들지만, 장기적인 증상 호전으로 인해 궁 극적으로는 치료비용이 감소할 수도 있다. 이를 명확히 규명 하는 것은 개인적인 차원에서 치료법 선택에 도움을 줄 수 있 을 뿐 아니라 보험정책의 수립에도 영향을 줄 수 있다. 서유 럽과 북미 국가에서는 면역치료의 비용효과분석에 대해 다 수의 연구가 진행되었는데, 공통적으로 알레르기 비염에서 면역치료는 증상 호전에는 효과적이지만 일반적인 약물치료 보다 상당한 비용이 추가되는 것으로 발표하였다. ${ }^{8-15)}$ 하지만, 비용효과분석은 개별 국가의 의료 시스템과 의료 비용에 따 라 달라지므로 국가별로 시행되어야 하는데 아직 국내에서 알레르기 비염 환자의 면역치료에 관한 장기간의 분석이 이 루어지지 않았다.

본 연구의 목적은 알레르기 비염 환자에서 면역치료의 비 용효과분석을 시행하여 치료의 선택과 보험정책 결정에 도움 을 주는 것이다.

\section{대상 및 방법}

\section{대상군 선정}

집먼지진드기 2종에 감작되어 지속적이고 중등-중증인 성 인 알레르기 비염 환자로 천식은 동반되지 않은 것으로 가정 하였다. 집먼지진드기를 선정한 이유는 한국인에서 가장 흔 한 호흡기 알레르기 원인이며, 국내에서 시판되는 대부분의 면역치료제가 집먼지진드기를 대상으로 하기 때문이고, 지속 적이고 중등-중증인 경우를 선정한 이유는 면역치료가 대 부분 이 분류의 환자들을 대상으로 진행되기 때문이다. ${ }^{5,16)}$ 성인을 선정한 이유는 본 연구에서 참조한 자료가 대부분 성 인을 대상으로 하였고, 소아에 대한 자료는 부족하였기 때문 이다. 의원에서 치료받는 것을 가정한 이유는 2019년에 비염 치료의 $81.3 \%$ 가 의원급에서 이루어졌고, 알레르기 비염은 경증 질환으로 분류되어 앞으로도 의원급에서 더 많은 진료 가 이루어질 것으로 예상되기 때문이다. ${ }^{17}$

\section{치료 모델}

알레르기 비염의 치료는 다음 3 가지 모델을 설정하였다.

\section{일반적 약물치료 모델}

면역치료나 수술은 받지 않고 경구 항히스타민제나 비강 내 스프레이 등 증상조절 약물만을 사용하여 대증적인 치료 만을 시행하는 경우이다. 최초 의원 방문 시 알레르기 원인 검사를 위해 multiple antigen simultaneous test(MAST)를 1 회 시행하고 첫 해에 모두 6회 병원을 방문하여 약물을 처 방받는 것으로 설정하였다. 검사 방법으로 알레르기 피부반 응검사나 항원특이적 $\mathrm{IgE}$ 검사 대신 MAST를 선택한 이유는 2009 2014년까지 알레르기 검사 중 MAST 처방이 가장 많 았기 때문이다. ${ }^{18)}$ 외래방문 횟수를 6회로 정한 근거는 2019년 국내의 전체 비염 환자 1 인당 외래 방문횟수가 평균 약 2.6 회 인데 본 연구의 대상자인 지속적이고 중등-중증인 환자들은 평균의 2 배 이상 외래를 방문할 것으로 추정하였기 때문이 다. ${ }^{17)}$ 이후 매해 증상의 경감에 비례하여 외래방문 횟수와 약 물비용이 변하는 것으로 가정하였다.

\section{피하면역치료 모델}

피하면역치료는 Tyrosin S(Allergy Therapeutics, London, $\mathrm{UK}$ 를 사용하여 3 년간 시행한다고 가정하였다. ${ }^{19,20)}$ 피하면역 치료 주사제는 비급여 항목이므로 제품마다, 또 처방하는 병 원마다 가격이 상이할 수 있는데, 정확한 가격 파악을 위해서 본 병원에서 사용하는 약제를 선택하였다. 피하면역치료 주사 제의 투여 용량과 일정도 상이한데, 1 주 간격으로 16 회(약 4개 
월)에 걸쳐 증량하고 그 후 매달 1회 방문하여 유지 요법 용 량을 주사하는 것으로 가정하였다. MAST 검사는 피하면역 치료 3년간 매년 1회씩 시행하는 것으로 가정하였다. 치료기 간을 3년으로 한정한 이유는 면역치료의 순응도가 매우 낮기 때문에 더 이상 긴 치료기간은 실제 상황과 괴리가 더욱 커질 수 있다고 판단했기 때문이다. 피하면역치료를 받는 경우도 증상에 비례하여 증상조절 약물치료를 병행하는데, 외래방문 횟수의 경우는 피하면역치료를 시행받는 3년간은 피하면역치 료를 위한 방문 시 약물을 처방받는 것으로 가정하고, 그 이 후는 일반적 약물치료 모델과 마찬가지로 매해 증상의 경감 에 비례하여 외래방문 횟수가 변하는 것으로 가정하였다.

\section{설하면역치료 모델}

설하면역치료는 Staloral 300(Stallergenes Greer, London, $\mathrm{UK}$ )를 사용하여 3 년간 시행한다고 가정하였다. ${ }^{19,20)}$ 설하면역 치료제 또한 비급여 항목이므로 제품에 따라 처방하는 병원 마다 가격이 상이할 수 있는데, 정확한 가격 파악을 위해서 본 병원에서 사용하는 약제를 선택하였다. 설하면역치료제 의 투여 용량과 일정도 제품마다 상이한데, Staloral 300의 경우 증량을 위한 초기치료 세트와 유지를 위한 유지치료 세 트로 나뉘어져 있다. 일반적으로 초기치료 세트의 경우 1.5 2달, 유지치료 세트의 경우 2.5 3달 정도 사용하므로, 첫해 에는 5 회 방문하여 처방을 받고(초기치료 세트 1 회/유지치료 세트 4회), 그 이후 2년은 4회 방문하여 처방을 받는 것으로 가정하였다(유지치료 세트 4회). MAST 검사의 경우 피하면 역치료와 마찬가지로 3 년간 매년 1회씩 시행하는 것으로 가 정하였다. 치료기간을 3 년으로 한정한 이유는 피하면역치료 에서 언급한 바와 같이 낮은 순응도를 반영했기 때문이다. 설 하면역치료를 받는 경우도 증상에 비례하여 증상조절 약물 치료를 병행하는데, 외래방문 횟수의 경우는 설하면역치료를 시행받는 3년간은 설하면역치료를 위한 방문 시 약물을 처 방받는 것으로 가정하고, 그 이후는 일반적 약물치료 모델과 마찬가지로 매해 증상의 경감에 비례하여 외래방문 횟수가 변하는 것으로 가정하였다.

\section{비용 분석}

상기 기술한 알레르기 비염의 3 가지 치료 모델에 대해 치료 시작부터 치료 후 7년까지의 비용 분석을 보건의료체계 관점 에서 시행하였다. 보건의료체계 관점에서 비용 분석을 시행하 였으므로 비용 항목에서 생산성 손실 비용은 제외하고 의료 비용과 비의료비용만을 계산하였다. ${ }^{7)}$ 의료비용에서는 비공 식적 의료비용은 제외하고 공식적 의료비용만을 포함하였고, 비의료비용에서는 간병비용은 제외하고 교통비용과 시간비
용만을 포함하였다.) 과거 자료를 참조하여 비용을 추정한 경 우는 2019년을 기준으로 물가상승률을 고려해 환산하였는데, 계산은 통계청에서 제공하는 화폐가치계산기(http://kostat. go.kr/incomeNcpi/cpi/cpi_ep/2/index.action?bmode=pay) 를 사용하였다. 미래에 발생할 비용에 대해서는 $5 \%$ 할인율을 적용하였다. ${ }^{7)}$

\section{비용 분석을 위한 가정과 치료 후 증상변화 예측}

본 연구에서 저자들은 알레르기 비염의 증상이 호전되면 그에 비례하여 병원방문 횟수와 약물비용이 감소할 것이라고 가정하였다. 이러한 가정하에 Marogna 등릐 의 연구결과를 참 조하여 병원방문 횟수 및 약물비용을 추정하였다. 상기 연구 는 장기간에 걸쳐 일반적 약물치료와 설하면역치료의 효과를 비교하였는데, 구체적으로 설하면역치료를 각각 3년, 4년, 5년 시행한 환자군과 일반적 약물치료만을 시행한 환자군을 전 향적으로 15 년간 관찰하면서 매해 증상-약물 점수를 기록하 였는데, 본 연구에서는 이중 설하면역치료를 3년간 시행한 환 자군과 일반적 약물치료만을 시행한 환자군의 10 년간 자료만 을 이용하였다. 매해 연초와 연말의 증상-약물 점수 평균을 그 해의 증상-약물 점수라고 정의하였고, 치료 시작 첫해의 일반적 약물치료 환자군의 증상-약물 점수를 기준으로 상대 적인 증상-약물 점수를 계산하여 이후 예측의 기준으로 사 용하였다(Fig. 1). 결과를 보면 설하면역치료 환자군에서는 치료를 시작한 첫 해부터 급격하게 증상-약물 점수가 감소하 여 치료를 마친 4년 후까지도 지속적으로 감소하다가 이후부 터는 다시 증가하는 양상을 보인다. 일반적 약물투여 환자군 에서도 증상-약물 점수가 서서히 감소하는 양상을 보이는데 그 폭은 크지 않았다.

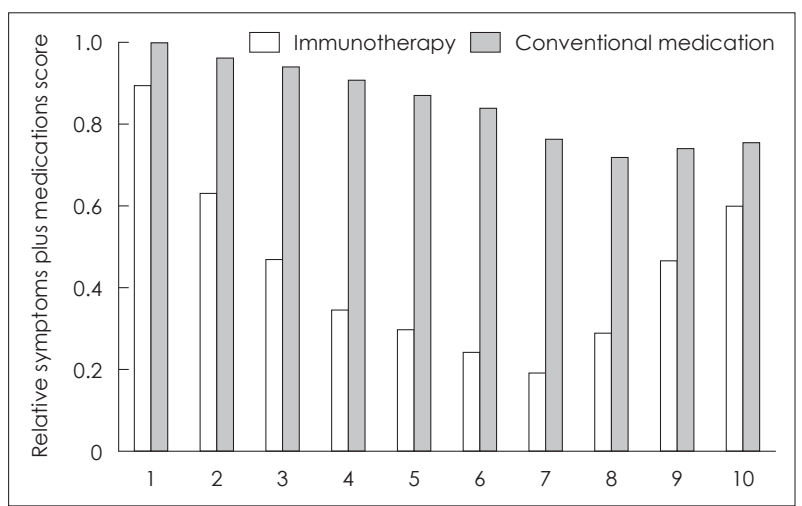

Fig. 1. 10-year change in the relative symptoms plus medications score in allergic rhinitis patients after immunotherapy and conventional medication. In the immunotherapy group, the relative symptoms plus medications score rapidly decreased from the first year of treatment, and continued to decrease until 4 years after treatment, and then increased again. The relative symptoms plus medications score also gradually decreased in the conventional medication group, but the degree was not large. 
피하면역치료의 효과는 설하면역치료와 동일하다고 추정 하고 상기 계산결과를 적용하였는데, 근거로는 1) 과거에는 피하면역치료의 효과가 더 우수하다는 연구 결과들이 있었으 나 두 치료법을 직접적으로 분석한 연구가 아니었고, ${ }^{6}$ 2) 국내 연구진에 의한 메타분석에서는 두 치료법의 효과가 차이가 없다고 발표되었으며, ${ }^{22)}$ 3) 두 치료법을 직접적으로 분석한 연구에서도 결과가 비슷하였다. ${ }^{23)}$ 또한 피하면역치료에 대해 Marogna 등 ${ }^{21)}$ 의 연구와 같이 장기적인 효과를 분석한 연구 가 없는 점도 고려되었다.

\section{의료비용}

의료비용에는 진료비용, 검사비용, 약제비용, 부작용 치료 비용 등이 포함된다.

\section{진료비용}

진료비용은 2020년 건강보험요양급여비용에 근거하여 1회 의 초진 진찰료 16140 원과 그 이외에는 모두 재진 진찰료 11530 원을 책정하였다. 피하면역치료의 경우 1 회 주사비 4000원이 추가되었다. ${ }^{24)}$

\section{검사비용}

검사비용도 2020 년 건강보험요양급여비용에 근거하여 MAST 검사 1 회당 209260 원을 책정하였다. ${ }^{24)}$

\section{약제비용}

약제비용의 경우 증상조절 약물과 면역치료제로 나누어 책 정하였다. 증상조절 약물의 경우 신상진 등 ${ }^{22)}$ 이 2012년 발표 한 보고서를 근거로 계산하였는데, 상기 보고서는 알레르기 비염으로 국내의 모대학병원에서 피하면역치료를 시행받은 161 명의 의무기록을 조사하여 천식증상 조절을 위한 약제는 제외하고 비염관련 약제만을 대상으로 성분별 가중평균 또는 상한가를 고려하여 매해 비용을 산출하였다. 이 중 피하면역 치료 첫해의 비염관련 약제비용을 본 연구에서는 1 년간의 증 상조절 약물비용으로 책정하였다. 당시 비용은 854864원이였 는데 물가상승률을 고려해서 925817원을 책정하였다. 면역치 료제 비용은 본 병원에서 현재 청구하는 비용을 책정하였는 데, 피하면역치료제(Tyrosin S)는 단가가 264000원이며 치료 기간내에 모두 9개를 사용하며, 설하면역치료제(Staloral 300) 는 단가가 350000 원이며 치료 기간 내에 모두 13 개를 사용 한다.

부작용 치료 비용

신상진 등 ${ }^{22}$ 의 보고서에 의하면 피하면역치료 중 성인에게
서 아나필락시스 등의 심각한 부작용이 없었으며 그 외 부작 용도 미미하여 큰 비용이 발생하지 않았다. 설하면역치료는 피하면역치료에 비해 더욱 안전한 것으로 알려져 있다. ${ }^{21)}$ 따 라서 본 연구에서는 비용을 따로 책정하지 않았다.

\section{비의료비용}

비의료비용으로는 교통비용과 시간비용을 고려하였다.

교통비용

교통비는 2005년 국민건강영양조사의 결과에 물가상승률 을 고려하여 계산하였는데, 당시 의원에 방문하기 위한 편도 교통비가 1378원이였다. 따라서 왕복은 2756원이며 물가상승 률을 고려하면 1회 외래방문 시 교통비용은 3684원이다. ${ }^{22)}$

\section{시간비용}

시간비용은 환자가 의료기관에서 치료를 받은 시간뿐 아니 라 의료기관까지의 왕복 교통시간과 진료를 기다리는 시간 및 약국을 이용한 시간을 모두 비용으로 환산한 것이다. 신상진 등 $^{22)}$ 의 보고서에 의하면 피하면역치료를 받을 때는 약 1.77 시 간이 소요되며, 일반적 약물치료를 받는 경우는 1.27 시간이 걸렸다. 설하면역치료도 주사치료가 필요없이 약물만 처방받 으면 되므로 일반적 약물치료와 같은 1.27 시간이 걸린다고 추정하였다. 통계청 자료(http://kosis.kr/index/index.do)에 따르면 한국의 2019년 연간 15 64세의 고용률은 66.8\%이 며, 전체 근로자의 시간당 임금총액은 20573 원이였다. 이들 자료를 근거로 피하면역치료 1회 방문에 24325원(1.77×0.668 $\times 20573$ 원)이 책정되었고, 일반적 약물치료와 설하면역치료 의 경우 1 회에 17453 원 $(1.27 \times 0.668 \times 20573$ 원)이 책정되었다. 단, 피하면역치료의 경우 3 년간의 치료가 끝난 이후에는 다 른 두 군의 시간비용과 동일한 17453 원으로 변경하였다.

본 연구는 직접적으로 환자를 대상으로 한 연구가 아니고 간접 자료만을 분석한 연구로서 기관생명윤리위원회의 승인 을 필요로 하지 않았다.

\section{결 과}

\section{일반적 약물치료 모델의 10 년간 비용 추계}

일반적 약물치료 모델의 첫해 치료비용은 1332489 원이었지 만, 이후 MAST 검사를 더 이상 시행하지 않았고 증상-약물 점수도 조금씩 감소하여 치료비용도 감소하였으나 큰 폭은 아 니었다. 할인율을 적용한 3년간의 누적비용은 3330199원이였 고, 10 년간의 누적비용은 7996087 원이였다. 자세한 결과는 Table 1에 제시하였다. 


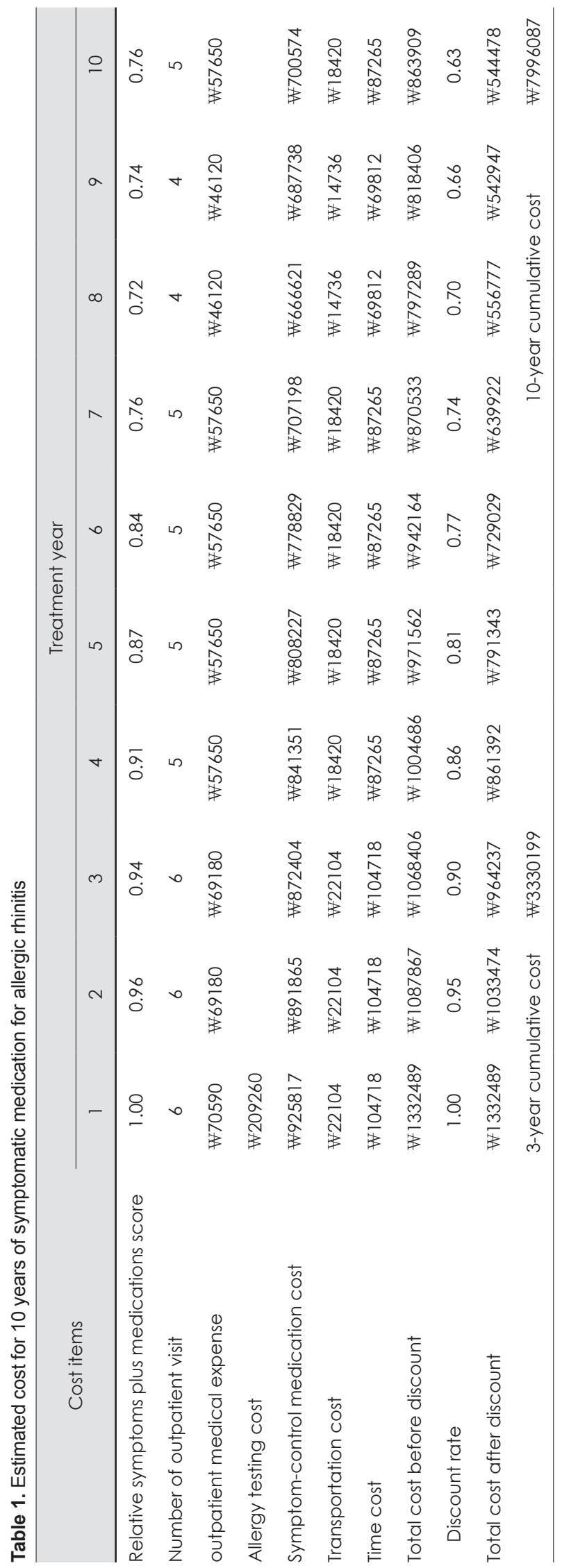

\section{피하면역치료 모델의 10 년간 비용 추계}

피하면역치료 모델의 경우 3 년간의 면역치료 기간 동안 면 역치료제 비용뿐 아니라 빈번한 외래방문으로 인해 진료비 용, 교통비용, 시간비용도 많이 소요되었다. 또한 매해 시행한 MAST 비용도 더해져 할인율을 적용한 3년간의 누적비용은 6605557원이였다. 하지만 치료 첫해부터 증상-약물 점수가 급격히 감소해 3년 이후의 치료비용은 일반적 약물치료 모델 에 비해 크게 감소한다. 다만 치료 시작 8년째부터는 다시 증 상-약물 점수가 조금씩 증가해 치료비용 또한 증가하게 되어 최종적으로 할인율을 적용한 10년간의 누적비용은 8588624 원이다. 자세한 결과는 Table 2에 제시하였다.

\section{설하면역치료 모델의 10 년간 비용 추계}

피하면역치료 모델의 경우 면역치료제 비용이 매우 비싸고, 3 년간 매해 MAST를 시행하는 비용도 더해져 할인율을 적 용한 3년간의 누적비용은 가장 세가지 치료 모델 중 가장 큰 7130467원에 이른다. 하지만 피하면역치료 모델과 마찬가지 로 치료 첫해부터 증상-약물 점수가 급격히 감소하고 8년 이 후에 조금 증가하여 할인율을 적용한 10년간의 누적비용은 9113534원이다. 자세한 결과는 Table 3에 제시하였다.

\section{세가지 치료 모델의 누적 증상-약물 점수의 비교}

10 년간의 상대적 증상-약물 점수의 누적 합계는 일반적 약 물치료 모델의 경우 8.51 이고, 피하면역치료 모델과 설하면역 치료 모델의 경우 4.44였다(Fig. 1). 따라서 면역치료는 일반적 약물치료에 비해 10년간 증상-약물 점수를 $0.44(=8.51 / 4.44)$ 배 감소키는 효과가 있다고 할 수 있다.

Fig. 2는 일반적 약물치료에 비해 면역치료 시 소요되는 비 용과 증상 감소 정도를 그래프로 나타낸 것이다. 치료 3년째 피하면역치료의 경우 일반적 약물치료와 비교해 약 330만 원 이 더 소요되고, 설하면역치료의 경우는 380만 원이 더 소요 되는 반면, 누적 증상-약물 점수 감소는 0.91점에 불과하다. 하지만, 치료 10년째에 이르면 일반적 약물치료와 비교해 피 하면역치료의 경우 약 59 만 원, 설하면역치료의 경우 약 110 만 원 더 소요되지만, 누적 증상-약물 점수는 4.1점이나 감소 한다.

\section{고 찰}

본 연구 결과를 간략히 정리해 보면 1) 성인 알레르기 비염 환자들이 일반적 약물치료를 받을 경우 3년간은 약 3300000 원, 10 년간은 약 8000000 원의 비용이 소요된다. 2) 피하면역 치료나 설하면역치료를 시행하면 3년의 치료기간에는 각각 
Cost-Effectiveness of Immunotherapy I Park JY, et al.
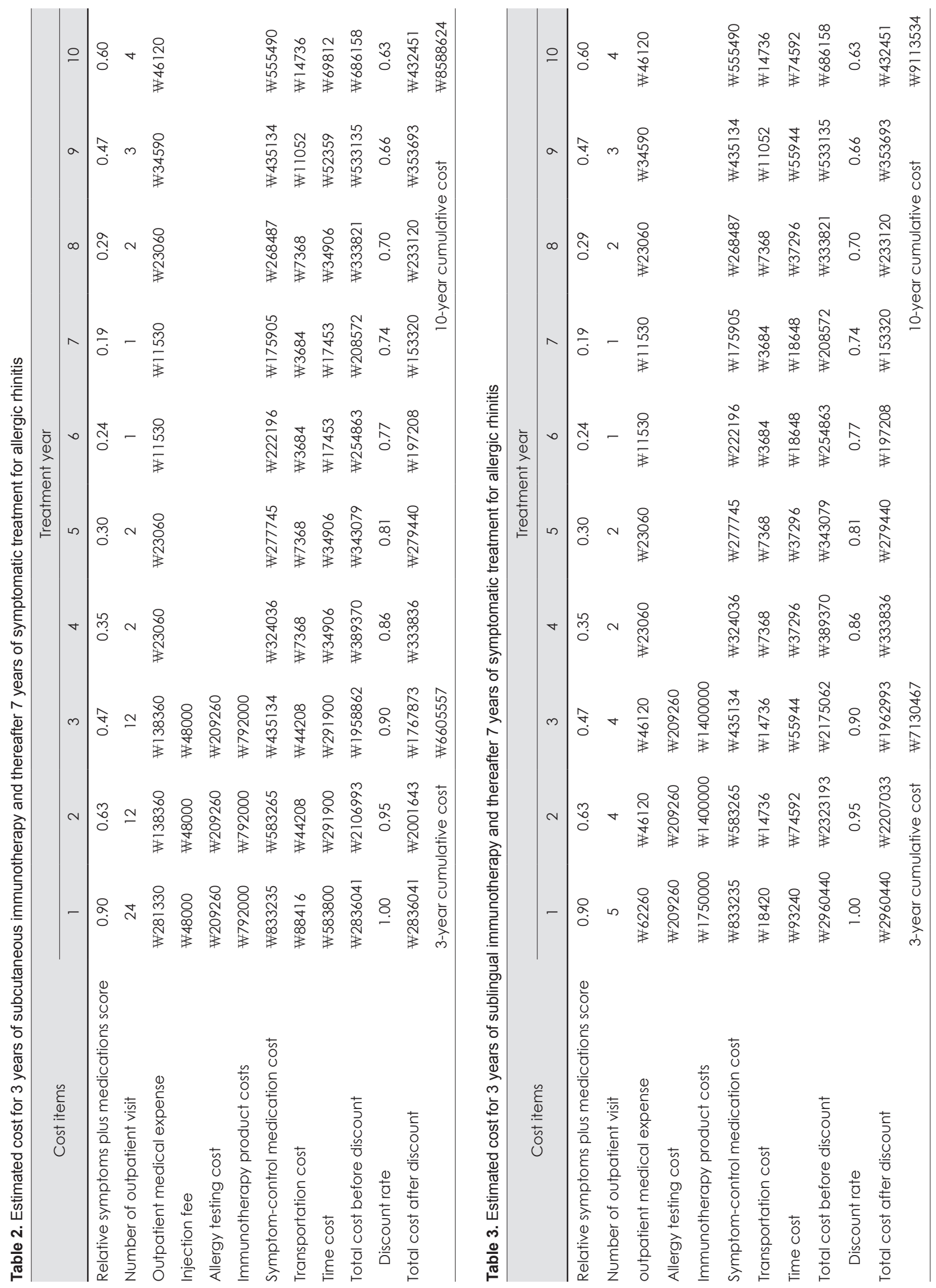


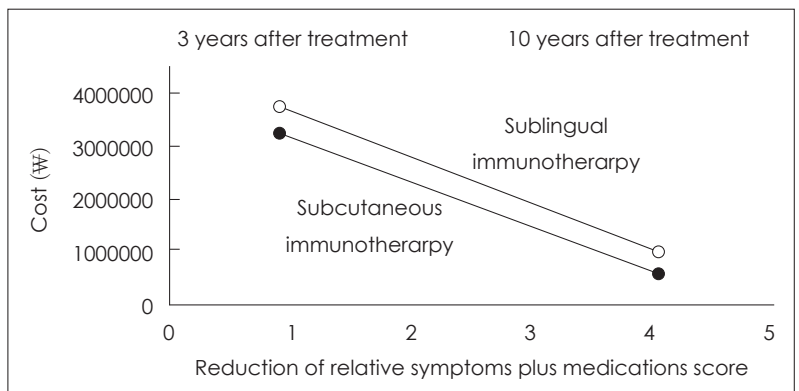

Fig. 2. Analysis of differences in symptoms and costs of immunotherapy compared to conventional medication. For the third year of treatment, subcutaneous immunotherapy costs about 3.3 million won more than conventional medication and sublingual immunotherapy costs 3.8 million won more, while the cumulative symptoms plus medications score decrease is only 0.91 . However, at the 10th year of treatment, it takes about 0.6 million won more for subcutaneous immunotherapy and 1.1 million won more for sublingual immunotherapy, but the symptoms plus medications score decreases by 4.1 .

약 6600000원과 7100000원으로 일반적 약물치료에 비해 많 은 비용이 필요하지만, 이후 알레르기 비염 증상이 급격히 호 전되어 10년간의 비용은 각각 약 8600000원과 9100000 원으 로 일반적 약물치료와 비교해 큰 차이가 없다. 3) 더구나 면역 치료의 경우 10 년간 환자가 겪을 비염 증상을 일반적 약물치 료만을 시행한 경우와 비교해 반 이상 경감시킬 수 있다.

알레르기 비염의 면역치료에 대한 비용효과분석은 외국에 서 다수 진행되었는데, 대부분의 연구에서 피하면역치료와 설 하면역치료 모두 일반적인 대증적 약물치료에 비해 증상 조절 에 있어서는 효과적이고 약물의 사용량도 줄어들지만 비용은 많이 든다고 발표하였다. ${ }^{8-15)}$ 비용효과분석을 객관적으로 평 가하기 위해 점증적 비용-효과비(incremental cost-effectiveness ratio)를 계산하는데, 이는 관심 질환이 완벽하게 조 절된 1년을 의미하는 질보정수명(quality-adjusted life years) 한 단위를 개선하기 위해 소요되는 비용을 의미한다. ${ }^{25)}$ 면역 치료에 관한 무작위 배정 연구 결과만 대상으로 점증적 비 용-효과비를 살펴보면 2014 2015년을 기준으로 영국의 경우 10726 16440유로, 덴마크 18824유료, 호주 8866유로, 독일 8334 11460유로, 네덜란드 22374유로, 스웨덴 20691유로 등 이다. ${ }^{8-15)}$ 이처럼 국가마다 다소 상이하지만 서구 선진국에서 면역치료에 상당한 비용이 들어간다는 점은 공통적이다. 본 연구에서 보면 우리나라에서도 면역치료가 일반적 약물치료 와 비교해서 처음 3 년간은 300 만 원 이상의 비용이 더 들어 가지만, 10 년간을 비교하면 일반적 약물치료와 비슷하다. 점 증적 비용-효과비를 구하지 못했기 때문에 다른 국가와 수평 적인 비교는 어렵지만, 의료비가 저렴한 우리나라에서는 면역 치료도 보다 저렴하게 시행할 수 있어 점증적 비용-효과비가 저렴할 것으로 추정된다.
비용분석에서는 비용분석의 관점도 매우 중요하다. ${ }^{7)}$ 본 연 구는 보건의료체계 관점에서 비용을 분석하였다. 이는 의료 비용과 교통비용, 시간비용, 간병비용 등 비의료비용을 모두 아우르며, 특히 의료비용에서는 보험자 부담비용과 환자 부 담비용을 모두 포함한다. 반면 환자 관점에서 진행되는 비용 분석에서는 환자가 부담하는 공식적 의료비용만을 고려한다.) 본 연구를 환자 관점에서 분석하였다면 교통비와 시간비용은 고려하지 않고 외래 진료비, 검사비, 증상조절 약제비 총합이 $20 \%$ 정도로 감소할 경우 일반적 약물치료 모델의 비용은 급 격히 줄어드는 반면, 면역치료 모델의 경우 면역치료제가 보 험적용이 되지 않아 비용감소가 크지 않아 일반적 약물치료 모델과의 비용차이는 더욱 커지게 되며, 환자 입장에서는 면 역치료를 받기가 더욱 부담스러울 수 있다. 다만 환자들의 경 우 본인부담금만 지불하는 것이 아니고 지속적으로 보험료를 납부하고 있고 실제 교통비와 시간비용은 필연적으로 발생하 는 것이기 때문에 환자 관점보다는 포괄적인 보건의료체계 관 점에서 비용분석을 진행하는 것이 합리적이라 생각된다.

하지만 면역치료를 받으면 10년간 증상이 반 이상 감소한다 는 점도 충분히 고려되어야 한다. 알레르기 비염은 삶의 질을 심각하게 저하시킨다는 것은 잘 알려진 사실인데, ${ }^{26)}$ 본 연구 결과와 같이 면역치료로 알레르기 비염 증상을 반 이상 경감 시키면 삶의 질도 크게 호전될 것이다. 비용효과분석의 핵심 도 일정 효과를 달성하기 위해 비용이 얼마나 투입되어야 하 는가를 규명하는 것이다. 본 연구 결과를 비용효과 분석적 관 점에서 보면, 면역치료를 위해 10년간 60 110만원의 비용을 더 사용하면 일반적인 약물치료에 비해 절반 이상 증상을 경 감시킬 수 있는 것이고, 결과적으로 삶의 질은 2 배 증가시킬 수 있다. 따라서 알레르기 비염에서 면역치료는 매우 비용효 과적인 치료법이라고 할 수 있다.

비용효과분석을 시행하기 위해서는 우선 특정 질환에 대한 치료모델을 만들어야 한다. 이 치료모델에 따라 비용효과분 석 결과는 크게 달라지므로 실제 의료상황을 정확히 반영할 수 있도록 만들어야 한다.) 하지만 특정 질환에 대한 대략적 인 치료과정은 비슷할 수 있어도 구체적인 치료과정은 의사 들마다 상의하며 환자에 따라서도 달라질 것이기 때문에 어 떤 것을 대표적인 치료과정이라고 단정하기는 어렵다. 알레 르기 비염 환자의 치료에서도 비록 Allergic Rhinitis and its Impact on Asthma라는 공인된 가이드라인이 있지만, ${ }^{27)}$ 큰 지침만 제시하고 있어 구체적인 치료법은 의사들마다 상이할 수밖에 없고, 더구나 모든 의사들이 이 가이드라인을 따르지 도 않는다. 따라서 의사마다 선호하는 알레르기 검사방법, 처 방하는 약물의 종류와 용량, 외래 방문주기 등도 매우 다양 할 것이며, 환자의 증상이나 치료에 대한 반응, 선호도 등에 
따라서도 치료과정은 크게 달라질 것이다. 건강보험통계, 국 민건강영양평가 등의 자료가 있지만 이 또한 구체적 의료상 황을 정확히 반영하기는 어렵다. 따라서 관련된 통계자료와 가이드라인 등을 최대한 이용하여 연구자가 생각하는 가장 보편적인 치료과정을 모델로 구현하게 되는데, 이러한 이유 로 비용효과분석의 결과는 연구자에 따라 상당히 상이할 수 있다. 특히 피하면역치료 모델의 경우 국내에 시판되고 있는 약제도 다양하며 투여 용량과 일정도 공인된 것이 없기 때문 에 대표적인 모델을 정하는 것은 어려웠다. 본 연구에서는 명 확한 스케줄과 비용을 알고 있는 본 병원의 경우를 기준으 로 모델을 만들었지만, 치료과정에 따라 분석결과가 상당히 달라질 수 있다는 점은 본 연구의 한계이다. 반면 설하면역치 료 모델의 경우 국내에 시판되고 있는 약제의 종류도 한정되 어 있고, 용량과 스케줄도 명확히 정해져 있는데 제품마다 거의 비슷하기 때문에 본 병원의 경우를 모델로 삼아도 큰 문제는 없을 것이라 생각한다.

그 외에도 본 비용효과분석에는 추가적인 한계가 있음을 밝힌다. 첫째, 알레르기 환자들의 치료 후 증상 변화를 $\mathrm{Ma}-$ rogna 등 ${ }^{21)}$ 의 연구결과만을 근거로 추정하였다. 면역치료가 위약에 비해 효과적이라는 연구는 무수히 많지만 면역치료의 효과를 일반적 약물치료와 비교해 10 년 이상 장기적으로 진 행한 연구는 Marogna 등 ${ }^{21)}$ 의 연구가 유일하였기 때문이었다. 더욱이 설하면역치료에 관한 연구결과인데 피하면역치료에 까지 적용하였다. 둘째, 본 연구에서는 면역치료를 3년간 시 행한 경우를 가정하고 분석한 것으로, 실제 면역치료의 낮은 순응도를 고려하지는 않았다. ${ }^{5)}$ 셋째, 면역치료의 장점인 천식 진행의 억제에 관한 사항은 비용분석이나 효과에서 고려하 지 않았다. ${ }^{5)}$ 만약 이를 포함하였다면 면역치료는 일반적 약 물치료에 비해 비용은 저렴해지고 효과는 컸을 것이다. 하지 만 장기간의 치료과정 중 천식의 발생률 및 치료비용에 관한 정확한 자료가 없어 고려할 수 없었다. 넷째, 증상조절 약제 비용, 교통비용 등은 상당히 오래된 자료를 이용하였는데, 최 신 자료를 구할 수 없었기 때문이다.

결론적으로, 알레르기 비염 환자에서 면역치료는 비록 초 기 비용은 일반적 약물치료에 비해 증가하지만 10년간의 장 기적 비용을 고려하면 비슷한 수준이 된다. 더욱이 알레르기 비염 증상은 평균적으로 반 이상 줄여주므로 비용효과적인 치료라고 할 수 있겠다. 다만 면역치료의 낮은 순응도나 상이 한 치료 효과는 충분히 고려되어야 한다.

\section{Acknowledgments}

This study was conducted under the advice of Professor Hyeyoung Jeong of Cornell Medical School.

\section{Author Contribution}

Conceptualization: Jae Hoon Cho. Data curation: Yoon-Sook Kim. Formal analysis: Joon Yong Park. Investigation: Joon Yong Park. Methodology: Jae Hoon Cho. Project administration: Jae Hoon Cho. Writing — original draft: Joon Yong Park, Jae Hoon Cho. Writing—review \& editing: Jin Kook Kim, Jae Hoon Cho.

\section{ORCIDs}

Jae Hoon Cho Joon Yong Park

Yoon-Sook Kim

Jin Kook Kim

\begin{abstract}
https://orcid.org/0000-0002-2243-7428
https://orcid.org/0000-0001-6003-9474

https://orcid.org/0000-0002-5936-0321

https://orcid.org/0000-0003-4245-6252
\end{abstract}

\section{REFERENCES}

1) Hur GY. Treatment of allergic rhinitis. Korean J Med 2013;85(5): 463-8.

2) Lee EH, Cha SH, Kim W. Socioeconomic burden due to allergic diseases. Suwon: Gyeonggi Research Institute;2016. p.1-114.

3) Cho SH, Kim YK, Sohn JW, Kim WK, Lee SR, Park JK, et al. Prevalence of chronic rhinitis in Korean children and adolescents. J Asthma Allergy Clin Immunol 1999;19(3):452-8.

4) Hwang SH, Jung SY, Lim DH, Son BK, Kim JH, Yang JM, et al. Epidemiology of allergic rhinitis in Korean children. Allergy Asthma Respir Dis 2013;1(4):321-32.

5) Rhee CS. Immunotherapy for allergic rhinitis: Current and future. Korean J Otolaryngol 2005;48(11):1312-22

6) Di Bona D, Plaia A, Leto-Barone MS, La Piana S, Di Lorenzo G. Efficacy of subcutaneous and sublingual immunotherapy with grass allergens for seasonal allergic rhinitis: A meta-analysis-based comparison. J Allergy Clin Immunol 2012;130(5):1097-1107.e2.

7) 김 윤 희, 신 상 진, 박 주 연, 정 예 지, 김 지 민, 이 태 진, et al. 보건의료분야에서 비용 산출방법. NECA;2013. p.1-181.

8) Dhami S, Nurmatov U, Arasi S, Khan T, Asaria M, Zaman H, et al. Allergen immunotherapy for allergic rhinoconjunctivitis: A systematic review and meta-analysis. Allergy 2017;72(11):1597-631.

9) Poulsen PB, Pedersen KM, Christensen J, Vestenbaek U. Economic evaluation of a tablet-based vaccination against hay fever in Denmark. Ugeskr Laeger 2008;170(3):138-42.

10) Dranitsaris G, Ellis AK. Sublingual or subcutaneous immunotherapy for seasonal allergic rhinitis: An indirect analysis of efficacy, safety and cost. J Eval Clin Pract 2014;20(3):225-38.

11) Ronaldson S, Taylor M, Bech PG, Shenton R, Bufe A. Economic evaluation of SQ-standardized grass allergy immunotherapy tablet $(\operatorname{Grazax}(\mathbb{R}))$ in children. Clinicoecon Outcomes Res 2014;6:187-96.

12) Westerhout KY, Verheggen BG, Schreder CH, Augustin M. Cost effectiveness analysis of immunotherapy in patients with grass pollen allergic rhinoconjunctivitis in Germany. J Med Econ 2012; 15(5):906-17.

13) Verheggen BG, Westerhout KY, Schreder CH, Augustin M. Health economic comparison of SLIT allergen and SCIT allergoid immunotherapy in patients with seasonal grass-allergic rhinoconjunctivitis in Germany. Clin Transl Allergy 2015;5:1.

14) Reinhold T, Brüggenjürgen B. Cost-effectiveness of grass pollen SCIT compared with SLIT and symptomatic treatment. Allergo J Int 2017;26(1):7-15.

15) Simoens $S$. The cost-effectiveness of immunotherapy for respiratory allergy: A review. Allergy 2012;67(9):1087-105.

16) Im D, Yang YS, Choi HR, Choi S, Nahm H, Han K, et al. Prevalence of allergic disease in Korean adults: Results from the Korea National Health and Nutrition Examination Survey (2010-2012). Korean J Otorhinolaryngol-Head Neck Surg 2017;60(10):504-11.

17) 보건의료빅데이터 개방시스템. 국민관심질병통계. [cited 2020 Jun 
13]. Available from: URL: http://opendata.hira.or.kr/op/opc/ olapMfrnIntrsIlnsInfo.do.

18) 장광천, 정인혁, 진주현, 최정규. 국민건강보험 청구자료를 이용한 알레르기 질환의 검사와 비용에 관한 연구. Goyang: National Health Insurance Service Ilsanhospital;2017. p.1-71.

19) Roberts G, Pfaar O, Akdis CA, Ansotegui IJ, Durham SR, Gerth van Wijk R, et al. EAACI guidelines on allergen immunotherapy: Allergic rhinoconjunctivitis. Allergy 2018;73(4):765-98.

20) Wise SK, Lin SY, Toskala E, Orlandi RR, Akdis CA, Alt JA, et al. International consensus statement on allergy and rhinology: Allergic rhinitis. Int Forum Allergy Rhinol 2018;8(2):108-352.

21) Marogna M, Spadolini I, Massolo A, Canonica GW, Passalacqua G. Long-lasting effects of sublingual immunotherapy according to its duration: A 15-year prospective study. J Allergy Clin Immunol 2010v;126(5):969-75.

22) 신상진, 송현진, 박선영, 정예지, 박주연, 안정훈, et al. 알레르기 비염, 천식에서 설하면역요법과 피하주사면역요법의 임상적 유용성
비교: NECA - 주제공모연구. Seoul: NECA;2012. p.1-423.

23) You SH, Qin XY, Xu C, Qiu X, Luan ZL, Jia HX, et al. Comparison study of subcutaneous immunotherapy and sublingual immunotherapy in patients with allergic rhinitis. Lin Chung Er Bi Yan Hou Tou Jing Wai Ke Za Zhi 2016;30(9):689-93.

24) 건강보험심사평가원. 건강보험요양급여비용 2020년 3월판. [cited 2020 Jun 13]. Available from: URL: https://www.hira.or.kr/ ebooksc/ebook_577/ebook_577_202004101043022660.pdf.

25) Cohen DJ, Reynolds MR. Interpreting the results of cost-effectiveness studies. J Am Coll Cardiol 2008;52(25):2119-26.

26) Meltzer EO. Allergic rhinitis: Burden of illness, quality of life, comorbidities, and control. Immunol Allergy Clin North Am 2016; 36(2):235-48.

27) Brożek JL, Bousquet J, Agache I, Agarwal A, Bachert C, BosnicAnticevich S, et al. Allergic rhinitis and its impact on asthma (ARIA) guidelines-2016 revision. J Allergy Clin Immunol 2017;140(4):950-8. 